\title{
Zakat and SDGs: Impact Zakat on Human Development in the Five States of Malaysia
}

\author{
Eko Suprayitno \\ University of Malaya \\ Mohamed Aslam \\ University of Malaya \\ Azhar Harun \\ Universiti Utara Malaysia
}

\begin{abstract}
Zakat is intended to stimulate economic development, education, social, human resources empowerment, religion health, and insurance programs. The seven programs above are implemented by the Malaysian government to improve economic growth. The aim of the study is to examine the impact zakat on human development program in Malaysia using the Autoregressive Distributed Lag (ARDL) bound testing approach. The analysis was carried out for the period from 1980-2009. The finding of the research reveals that zakat has a positive and significant influence on human development in five state in the short and long run. Zakat in Malaysia can be used as tool of fiscal policy that is decided in the states of Malaysia to stimulate human development and economic growth in the long run.
\end{abstract}

Keyword: Zakat, Human Development, Granger causality test

\section{INTRODUCTION}

Zakat is regarded as one of the most important sources of fund available within the Islamic economic and financial system. Zakat is the main income for Islamic countries besides tax such as tax of land, tax of agriculture products, and others (Shalih, 1965). It is a part of human's wealth that is distributed to the have-not following the ordinance of Allah SWT. It is in line with the Holy Koran, Hadith, and Islamic teaching (Sabiq, 1973). It is the main mechanism used to reduce economic inequalities and alleviate misery within the Muslims community. Besides that, zakat also forms social bonds between Muslims, as in Islam all Muslim are family and it is important to help one another. The wealth owned by rich Muslims belongs to the poor and the needy and other eligible zakat recipients.

Education and training is one of the most important social investments as it will bring benefits to a country in the long run. The roles of education and training are: to produce knowledgeable, trained, and skilled workforce; to mould a disciplined, diligent, and motivated individual; to provide individuals who are innovative and knowledgeable in technology, management, and related skills, especially to the industrial sector. Malaysia introduced a comprehensive national education policy in the Education Act 1961. Among the objectives of the national education policy are as follows: to provide individuals greater access to education; to make Malaysian language as the main medium of instruction; to establish a common curriculum; to provide 
the teaching of the students' own languages; to emphasize on vocational and technical education; and to provide moral and religious education. To achieve the objectives of the National Education Policy, a number of programs were implemented such as: free education to all children up to upper secondary level; provision of teaching and educational facilities, and trained teachers; and to provide educational aids to assist the poor in the form of text book loans, scholarships, supplementary feeding, health, and dental services (Yussof, 2011).

Malaysia is committed to improve the level of education as it recognizes that education is an important ingredient in development. Malaysia's education system provides free education to students between the ages of 7 to 17 for a total of 11 years of universal education. Admission age to the first year of primary schooling is usually seven and the graduating age for a first bachelor degree is about 22 years. The primary and secondary school children would also get free textbooks provided by the government. The quality of education, access, and opportunities has improved to all strata of the society to provide manpower requirement to the nation. Recently, human capital formation has received an increased attention from policy makers and scholars interested in promoting economic development in developing countries. Models of endogenous economic growth stress the importance of investment in knowledge, including basic education, as a critical factor in economic growth and therefore education should form a principal component in any development strategy (Yussof, 2011).

\section{ZAKAT AND EDUCATION IN ISLAM}

Islam places great stress on seeking knowledge and education. Generally speaking, one can't find the proper right path in this world; this is true in all times and places. Knowledge is very important for two reasons. Firstly, it makes the man a right thinker; no one can think properly without having a fair amount of education. It also helps one take the right decision. Secondly, knowledge is that only through gaining many levels of education, man is able to gain more information from the external world. In fact, Islam called upon seeking out knowledge on all the levels. The first word of the Qur'an, revealed by God to prophet Muhammad (PBUH) was read, which highlights the importance of science and learning. The prophet (PBUH) said that seeking knowledge is a compulsory for every Muslim. He also said that whoever follows a path seeking knowledge, God will make his path to paradise. In Islam, the education process derives its pillars from the Holy Quran and Prophetic Traditions, and sayings of Companions, Followers, and the opinions of pedagogy scholars. From this balanced blend, the Islamic education derived its objectives, elements, means, and methods, in the context of integrated system organized by Islamic teachings. The education process in Islam is a process of building and directing individuals to reach its maturity. For this aim, messages were revealed and messengers were sent to build individuals spiritually, mentally, and physically, in the light of balanced system that enables them to perform his duties.

Specifically, education in Islam entails the acquiring of intellectual knowledge through the application of reasoning and logic and developing of spiritual knowledge based on the divine revelation and spiritual experience. From the Islamic world view, an Islamic education must strike a balance between the above a mentioned two aspects, as acquiring knowledge in Islam is a means to elevate moral and spiritual consciousness leading to faith and righteous actions. The major source of knowledge in Islam is the al-Qur'an. In 
fact, the first verse revealed by Allah in the al-Qur'an is on education:

\section{"Read! In the name of the Lord and the cherisher, who created man, out of a (mere) clot of congealed blood. Read! And the Lord is the most Bountiful; he who taught (the use of) the pen, taught the man what he knew not." Surah Al- Alaq:1-7.}

These verses remind Muslims that we must remember Allah, read the alQur'an, and seek knowledge. It is the responsibility of all Muslims to seek knowledge and discover facts through research and development to improve their standard of living. And indeed those who have knowledge will be exalted by Allah to high rank as the al-Qur'an says:

"Allah will exalt those who believe among you, and those who have knowledge, to high rank. Allah is informed of what you do." Surah Al-Mujadilah: 11.

The importance of the people who have knowledge is explained further by the Prophet (pbuh). He says:

"The learned ones are the heirs of the Prophets, they leave knowledge as their inheritance: he, who inherits, inherits a great fortune." Abu Daud.

This verse and hadith are evidences that the ulama or teachers are exalted describing them the heirs of the Prophets. It is important to teach knowledge to others as this knowledge is a great fortune because of its potential to create innovations and new technologies to increase the production capacity, income, and the standard of living. Indeed, the history of Muslim education goes back to the Prophet (PBUH) himself who taught his companions the al-Qur'an and its meanings as well as the foundation of Islamic jurisprudence.

The institution of zakat in Malaysia has an important role in micro and macroeconomics. This important role is not separated from the distribution of zakat to the asnaf especially to the faqir and the masakin. Zakat distribution in Malaysia is distributed for education and human resource empowerment. The rulers regarded the building of mosques and schools in their kingdoms as their divine responsibility. They also opened pious trusts (awqaf) as a means to provide a sustained physical and financial assistance to the teachers and scholars. Education is the process of increasing knowledge, the skills, and the capacities of all the people in a society or the accumulation of human capital for economic progress. The stock of human capital could be accumulated in a number of ways. First, it could be accumulated through formal education, beginning with primary education, followed by secondary education, and tertiary education in colleges and universities. Second, human capital is accumulated through on the job-training programs by the employers. A third process is through self-development where an individual takes an initiative to acquire more knowledge, skills, and capacities by reading, and learning by doing. Fourth, is the capital accumulation through the improvements in the health of the working population because of the existence of better medical and public health facilities and services? And the fifth is the capital accumulation as a result of better nutrition, which increases the working efficiency of the workers. The accumulation of human capital may start with formal education and continues on; it is a lifetime process as we have to update our knowledge and skills.

The Human Development program above is an important tool to achieve 
economic growth and strong economic fundamentals. The purpose of the study is to analyze the relationship between zakat and human development in the Federal Territory of Malaysia.

There are many studies on zakat, but few studies on influence of zakat on macroeconomic. Salleh and Rogayah Ngah (1980) conducted a study of farmers in Malaysia. This study examines inequality in income distribution before and after zakat distribution with Gini-coefficient approach. The result of the study that zakat is able to increase of income distribution among the farmers. Patmawati (2007) conducted a study of the zakat in Selangor, Malaysia, based on the 2001-2002 data. The resultof the study show that the distribution of zakat is reduced poverty rate, poverty gap, and reduced the income distribution gap in Selangor. The SenIndex and the FGT index decreased in the Selangor after zakat distribution. Reduction of poverty and income inequality reflects an increase in income to the zakat recipients as well as having an effect on the increase in public consumption.

Hassan (2010) develops the idea of integrated model that combines Islamic Microfinance with zakat and awqaf institutions for reduced the poverty. The model incorporates zakat which can be distributed to fulfill basic consumption needs whereas the Awqaf fund will be used as for business or capital investmen for the poor to involve in economic activity. As the proposed model is fully based on profit-loss sharing and concessional contract modes, the distribution of profit or earnings will be allocated as per the contribution of capital among the depositors, shareholders, investors in the NGO. Furthermore, the burden of debt is less on the poor under this model since the provision of zakat fund does not require any repayment. As the model is based on profit-loss sharing principle, no fixed interest payment will be imposed on the borrowers. It is argued that all these factors will lower the chances of default rates and thus contribute to higher success rate of poverty alleviation.

Yussof (2010) expanded the study to analyze the impact of zakat expenditure on real output in Malaysia. The study shows that the zakat influences the variations of output. Yussof (2011) studied the impact of zakat spending on school enrollment on economic growth using panel data. He found that zakat spending and school enrollment are important determinants of real output represented by the growth of real GDP. Suprayitno, Radiah, and Azhar (2013) investigated the impact of zakat distribution on aggregate consumption in Malaysia. The results of the study found that zakat expenditure has a positive relationship with aggregate consumption. Salama (1995) finds that in Sudan the portion of zakat expenditure was a high spend to the administrative expenditure.

\section{RESEARCH METHODOLOGY}

This study used annual data for the period from 1980-2009. This study also used data from five states in Malaysia, namely, Johor, Kedah, Negeri Sembilan, Selangor, and Terengganu. The zakat data in the five states in Malaysia are collected from the Annual Report of zakat Majlis Agama Islam Wilayah Persekutuan (MAIWP), Annual Zakat Report states of Malaysia, and the data of Gross Domestic Regional Product (HD) in the states of Malaysia are gathered from the Department of Statistical and Central Bank of Malaysia.

\subsection{The Model}

There are few studies on the modeling of zakat. Metwally (undated), Choudhury, and Malik (1992), Choudhury (1999) developed modeling on the impact zakat on the general equilibrium in Malaysia. In this current study, we specify our model depending on the Suprayitno, Radiah, and Azhar (2013) dan Yussof (2011) as: 
$H D_{i t}=\beta_{0}+\beta_{1} Z k_{i t}+\varepsilon_{i t}$

where $H D$ is the ratio of total enrollment in primary and secondary schools to the total population of the respective States. Secondary schools is included in junior high school and senior high schools. Zk is the nominal zakat in the States of Malaysia. $\beta$ 's the parameters to be estimated, and $\varepsilon_{i t}$ is a white noise error term, the subscript $\mathrm{i}$ represents states and $\mathrm{t}$ represents time period for each states. The hypothesiss of the study is the zakat expenditure has positively related to the enrollment ratio; an increase in zakat would raise enrollment ratio.

\subsection{ADF Unit Root Test}

In order to determine stationary properties of the series, this study employs several tests, such as Augmented Dickey and Fuller $(A D F)$, Phillips and Perron $(P P)$ (1981). ADF unit root test using simple regression is following in equation (2):

ADFtest :

$\Delta Y_{t}=\propto+\delta t+\beta Y_{t-1}+\gamma \sum_{i=1}^{p} \Delta Y_{t-i}+\mu_{t}(2)$

where; $\Delta Y_{t}$ is the unit root test for $\mathrm{Y}_{\mathrm{t}}$ using natural logarithm for all variables (HD and $\mathrm{Zk}$ ) in the period of $\mathrm{t}$. Whereas, $\Delta Y_{t-i}$ is the lag of first difference. $\Delta$ denotes a symbol of difference. $\mu_{t}$ is an error term; $\alpha$, $\beta$, and $\delta$ are the parameters to be estimated. Because the bound test is assumed that the variables are integrated at $\mathrm{I}(0)$ or $\mathrm{I}(1)$. Hence, the implementation of unit root test in the ARDL procedure might still be necessary to ensure none of variables are $\mathrm{I}(2)$ or beyond.

\section{EMPIRICAL RESULT AND DISCUSSION}

\subsection{ADF Unit Root Test}

The first step for proceed the ARDL bound test is by testing the unit root to check the stationary of the variables. Table 2 presents the result of Unit Root Test Results. The results show that the variables are integrated at $\mathrm{I}(0)$ or $\mathrm{I}(1)$ at 1,5 , and $10 \%$ significance levels. 
Table 2 Unit Root Test Results

\begin{tabular}{lllll}
\hline \multicolumn{5}{c}{ Augmented Dickey-Fuller Test } \\
\hline States & Variable & Intercept & Intercept \& trend & Decision \\
\hline Johor & $\operatorname{lnZk}$ & $-3.286(1)^{* * *}$ & $-3.87(1)^{* *}$ & $\mathrm{I}(0)$ \\
& $\operatorname{lnHD}$ & $-3.86(1)^{* *}$ & $-5.63(0)^{*}$ & $\mathrm{I}(1)$ \\
Kedah & $\operatorname{lnZk}$ & $-5.27(1)^{*}$ & $-6.38(0)^{*}$ & $\mathrm{I}(1)$ \\
& $\operatorname{lnHD}$ & $-4.53(1)^{*}$ & $-6.20(0)^{*}$ & $\mathrm{I}(0)$ \\
N. Sembilan & $\operatorname{lnZk}$ & $-4.24(0)^{*}$ & $-7.57(0)^{*}$ & $\mathrm{I}(0)$ \\
& $\operatorname{lnHD}$ & $-4.96(0)^{*}$ & $-7.76(0)^{*}$ & $\mathrm{I}(1)$ \\
Selangor & $\operatorname{lnZk}$ & $-5.16(0)^{*}$ & $-8.03(0)^{* *}$ & $\mathrm{I}(1)$ \\
& $\operatorname{lnHD}$ & $-5.62(0)^{*}$ & $-8.22(0)^{* *}$ & $\mathrm{I}(1)$ \\
Terengganu & $\operatorname{lnZk}$ & $-4.73(1)^{*}$ & $-7.31(0)^{* *}$ & $\mathrm{I}(1)$ \\
& $\operatorname{lnHD}$ & $-5.03(0)^{*}$ & $-7.32(0)^{* *}$ & $\mathrm{I}(1)$ \\
\hline
\end{tabular}

$*, * *$ and $* * *$ denote significant at 1,5 , and $10 \%$ significance levels, respectively. Optimal lag length is determined by the Akaike Information Criteria (AIC).

\subsection{Engle and Granger Causality Test}

Granger causality test is used to know causality among the variables (Granger, 1969; Engle and Granger, 1987). Table 4 presents the result of Granger causality test using ARDL-ECM based on equation (7). Table 4 shows that, Johor, Kedah, Negeri Sembilan, Selangor, and Terengganu have are bi-directional causality hypothesis in the long run. In the short-run period, bi-directional causality hypothesis happens in the states of Kedah, Selangor, and Terengganu. Whereas, zakat influences the human development in the states of Johor and Negeri Sembilan. The consistent result of bi-directional causality hypothesis both short run and long run happens in the states of Kedah, Selangor, and Terengganu. The result of zakat influence on human development both in the short and the long run happens only in the states of Johor.

Table 4 Granger Causality Test with ECM

\begin{tabular}{|c|c|c|c|c|c|c|}
\hline State & $\begin{array}{c}\text { Dependent } \\
\text { variable }\end{array}$ & $\Delta \ln Z$ akat & $\Delta \ln H \mathrm{D}$ & $\Delta$ Constant & ECT & F-Statistic \\
\hline \multirow[t]{2}{*}{ Johor } & $\Delta \ln Z$ akat & & $\begin{array}{c}0.5303^{*} \\
(2.9382)\end{array}$ & $\begin{array}{r}0.1385^{* *} \\
(2.0476)\end{array}$ & $\begin{array}{r}-0.4605 * * \\
(-2.5067)\end{array}$ & $9.8604^{*}$ \\
\hline & $\Delta \ln H D$ & $\begin{array}{r}0.6131 \\
(1.0962) \\
\end{array}$ & & $\begin{array}{r}-2.4249 * * \\
(2.1390)\end{array}$ & $\begin{array}{l}-0.4827^{*} \\
(-2.0981)\end{array}$ & $5.4628 * *$ \\
\hline \multirow[t]{2}{*}{ Kedah } & $\Delta \operatorname{lnZakat}$ & & $\begin{array}{r}0.4217^{*} \\
(3.281)\end{array}$ & $\begin{array}{r}0.2129 * * \\
(2.1412)\end{array}$ & $\begin{array}{l}-0.3925^{*} \\
(-3.1011)\end{array}$ & $8.7119 *$ \\
\hline & $\Delta \ln H \mathrm{D}$ & $\begin{array}{r}0.4736^{* *} \\
(2.8106)\end{array}$ & & $\begin{array}{c}-0.4821^{*} \\
(4.0108)\end{array}$ & $\begin{array}{r}-0.3326^{* *} \\
(-2.3107)\end{array}$ & $9.1922 *$ \\
\hline \multirow[t]{2}{*}{$\begin{array}{l}\text { Negeri } \\
\text { Sembilan }\end{array}$} & $\Delta \ln Z$ akat & & $\begin{array}{c}0.1865^{*} \\
(3.0015)\end{array}$ & $\begin{array}{r}0.2341 * * \\
(2.2883)\end{array}$ & $\begin{array}{r}-0.4603 * * \\
(-2.5567)\end{array}$ & $9.2091^{*}$ \\
\hline & $\Delta \ln H \mathrm{D}$ & $\begin{array}{c}0.3862 * \\
(2.9832)\end{array}$ & & $\begin{array}{r}0.2089 * * \\
(2.1947)\end{array}$ & $\begin{array}{r}-0.4827 * * \\
(-2.6443)\end{array}$ & $8.0373 *$ \\
\hline \multirow[t]{2}{*}{ Selangor } & $\Delta \operatorname{lnZakat}$ & & $\begin{array}{c}0.4346^{*} \\
(4.5323)\end{array}$ & $\begin{array}{l}2.0543^{*} \\
(3.2099)\end{array}$ & $\begin{array}{c}-0.6264^{*} \\
(-3.6527)\end{array}$ & $10.2325^{*}$ \\
\hline & $\Delta \ln H \mathrm{D}$ & $\begin{array}{c}0.5442 * \\
(4.7860)\end{array}$ & & $\begin{array}{l}3.9077^{*} \\
(4.0021)\end{array}$ & $\begin{array}{c}-0.5498^{*} \\
(-3.7081)\end{array}$ & $9.7306^{*}$ \\
\hline \multirow[t]{2}{*}{ Terengganu } & $\Delta \operatorname{lnZakat}$ & & $\begin{array}{c}0.3276^{*} \\
(4.0521)\end{array}$ & $\begin{array}{r}0.9833^{* *} \\
(2.5316)\end{array}$ & $\begin{array}{r}-0.5159 * * \\
(-2.6702)\end{array}$ & $9.8005^{*}$ \\
\hline & $\Delta \ln H \mathrm{D}$ & $\begin{array}{r}0.4091 * \\
(3.2122)\end{array}$ & & $\begin{array}{c}0.3208^{*} \\
(3.5161)\end{array}$ & $\begin{array}{r}-0.5192 * * \\
(-2.5391)\end{array}$ & $8.5927^{*}$ \\
\hline
\end{tabular}

$*, * *$ and $* * *$ denote significant at 1,5 , and 10\% significance levels, respectively. Optimal lag length is determined by the Akaike Information Criteria (AIC). 
Table 4 shows the estimated of ECM. The coefficient of ECM is negative and significant at 1, 5, and $10 \%$ level. Its means that the adjustment process from the short-run deviation is fast, relative fast Negeri Sembilan, Selangor, and Terengganu with indicates that from 50\% above, relatively fast in the state of Johor and Kedah with 28\% - 39. This implies that there is a statistically significant shortrun positive impact of zakat on the Human Development in the state of Malaysia. The influence of zakat on Human Development in the state of Malaysia in the short and long run means zakat is one factor to decide fiscal policy in the states of Malaysia. This happens because zakat is a considered as saving instrument or collection for special budget that is definitely distributed to the poor and the needy such as human development program.

It means, that the more zakat are collected, more powerful for zakat to plays the important role in social life, social welfare, and economic development to substitute the role of the government through the government budget. Therefore, the increase of zakat collection in short run will increase zakat distribution and increase income of zakat recipients.

With this results suggest that the system management of the zakat in Malaysia is able to stimulate on the economic growth of the state in Malaysia. The various programs such as economic development, education, social, human resources empowerment, religious, health, and insurance are implemented for short and long run, programs fulfill basic needs, and sustainable programs, both physical and psychological needs as well as both material and spiritual needs. Zakat management model in Malaysia can be the model for other Islamic countries to stimulate economic growth.

\section{CONCLUSIONS AND \\ RECOMMENDATION}

This article proves that there is a causal relationship between zakat and economic growth in the State of Malaysia. Zakat influence on Human Development both in the short and the long run. In light of this, zakat in Malaysia can be used is one factor to decide fiscal policy in the states of Malaysia. Zakat can be the supportive fiscal policy to stimulate human development.

Beside forms that, zakat has the ability to influence economic activity. Zakat could be employed as an important tool to stimulate human development. The distribution of zakat for education and human resources empowerement is stimulate better social life of the recipients. Thus the increase of zakat in the short run is able to increase the social life, quality of education and quality of recipients. In the long run increase of the income, increasing in income will influence on consumption. In the long run is able to increase consumption, investment, demand for labor, and stimulate zakat recipient became zakat payers. In this case, the main goal the zakat to reach sustainable zakat funds and economic growth are successfully achieved.

\section{REFERENCES}

Choudhury, M. A. (1999). Comparative Economic Theory Occidental and Islamic Perspectives. Kluwer Academic Publishers. http://dx.doi.org/10.1007/978-14757-4814-7

Choudhury, M. A and Malik, U.A (1992).The Foundations of Islamic Political Economy. The MacMillan Press Ltd. London.

Dickey, D. \& Fuller, W. A. (1981). Likelihood Ratio Statistic for Autoregressive Time Series with a Unit Root. Econometrica, 49, 
1057-1072.

http://dx.doi.org/10.2307/1912517.

Phillips, P. C. B. \& Perron, P. (1988).

Testing for a Unit Root in Time

Series regression. Biometrical, 75,

335-446.

http://dx.doi.org/10.1093/biomet/75 .2 .335

Engle, R. F., \& Granger, C. W. J. (1987). Co-integration and error Correction: Representation, estimation and testing. Econometrica, 55: 251-276. http://dx.doi.org/10.2307/1913236

Granger, C. W. J. (1969). Investigating Causal relationship by econometric models and cross-spectral methods. Econometrica July: 424-438. http://dx.doi.org/10.2307/1912791; $\mathrm{s}$

Hassan, M. K. (2010). An Integrated Poverty Alleviation Model Combining Zakat, Awqaf, and Micro-Finance. Seven International Conferences - The Tawhidi Epistemology Zakat and Waqaf Economy, Bangladesh.

http://www.kep.org.sa/en/SideMenuConte nt_en.aspx?MenuID=97\&MenuTitl $\mathrm{e}=$ Education $\% 20 \mathrm{in} \% 20$ Islam

Ibrahim, Patmawati. Hj. (2007). Peranan Agihan Zakat dalam Meningkatkan Tahap Ekonomi Ummah, Kertas kerja dibentangkan dalam Konvensyen Zakat dan Cukai Peringkat Kebangsaan 2007 di PWTC, Kuala Lumpur.

Pesaran, H. M., Shin, Y., \& Smith, R. J. (2001).Bound Testing Approach to the Analysis of Level Relationship. Journal of Applied Econometrics, 16, $289 \quad-$ 326.http://dx.doi.org/10.1002/jae.6 16

Pesaran, H. M., \& Shin, Y. (1999). Autoregressive Distributed Lag Modeling Approach to Co integration Analysis, Chapter 11, in: Storm, S., (Ed). Econometrics and Economic Theory in the 20th
Century: The Ragnar Frisch Centennial Symposium (Cambridge: Cambridge University Press).http://dx.doi.org/10.1017/CC OL521633230.011

Pesaran, H. M., \& Shin, Y. (1999). Autoregressive Distributed Lag Modeling Approach to Co integration Analysis, Chapter 11, in: Storm, S., (Ed). Econometrics and Economic Theory in the 20th Century: The Ragnar Frisch Centennial Symposium. (Cambridge: Cambridge University Press).http://dx.doi.org/10.1017/CC OL521633230.011

Sabiq, as-Syaid. 1973. Fiqh as-sunnah. 2jilid. "Zakat" dijilid I. Beirut: Dar al-Kitab al-'Arabi.

Salama, A. A. (1995). Empirical Economics Effect of Obligatory and non-Obligatory Payment of Zakah to the State.In El-Ashker and SirajulHaq (Ed.).Institutional Framework of Zakah: Dimensions and Implications. Islamic Research and Training Institute, Islamic Development Bank.Jeddah.

Salleh, I, M., \& Rogayah, N. (1980). "Distribution of the Zakah Burden on Padi Producers in Malaysia, in M. Raquibuzzaman (ed.), Some Aspects of the Economics of Zakah, AMSS, Indiana, pp. 81-153.

Shalih, Subhi as-. 1965. Al-Nuzhum alIslamiyah:

NasyatuhawaTathawwuruha.

Beirut: Dar al-'Ilmi li-'1-malayin.

Suprayitno, E., Radiah A. K., \& Azhar H. (2013). The Impact of Zakat on Aggregate Consumption in Malaysia. Journal of Islamic Economics, Banking and Finance, Vol. 9 No. 1, Jan - Mar 2013. IBTRA, Bangladesh. pp, 39-62.

Yusoff, M. B. (2011). Zakat Expenditure, School Enrollment and Economic Growth in Malaysia. International Journal of Business and Social Science, 2(6), 175 - 181. 
Yusoff, M. B. (2010). An Analysis of Zakat Expenditure and the Real Output: Theory and Empirical Evidence. IIUM Journal of Economic and Management, vol 18(2), 139 - 160, Kuala Lumpur.

Yusoff, M. B. (2011). Zakat Expenditure, School Enrollment and Economic Growth in Malaysia. International Journal of Business and Social Science, 2(6), 175 - 181.

Eko Suprayitno

University of Malaya

Malaysia

ekonashwan@gmail.com

Mohamed Aslam

University of Malaya

Malaysia

Azhar Harun

Universiti Utara Malaysia

Malaysia 
